\title{
Effect of a Saccharomyces cerevisiae culture on growth and lactate utilization by the ruminal bacterium Megasphaera elsdenii
}

\author{
F Rossi ${ }^{1}$, PS Cocconcelli ${ }^{2}$, F Masoero ${ }^{1}$ \\ ${ }^{1}$ Istituto di Scienze degli Alimenti e della Nutrizione; \\ 2 Istituto di Microbiologia, Facoltà di Agraria, Università Cattolica del Sacro Cuore, \\ Via Emilia Parmense 84, 29100 Piacenza, Italy
}

(Received 22 November 1994; accepted 28 November 1994)

\begin{abstract}
Summary - This study evaluated the effect of a yeast culture (YEA-SACC) filter-sterilized filtrate on the growth and lactate uptake by the ruminal bacteria Megasphaera elsdenii. The levels of filtrate used $(\mathrm{v} / \mathrm{v})$ were $0,1,2.5,5 \%$. $\mathrm{M}$ elsdenii was cultured in ATCC 566 modified medium, under anaerobic conditions, for $24 \mathrm{~h}$ at $39^{\circ} \mathrm{C}$ in batch culture. The treatment caused a linear improvement in lactate utilization and bacterial dry matter production: a $60 \%$ increase over the control for a $5 \%$ YEA-SACC supplement. The addition of 2.5 and $5 \%$ of YEA-SACC resulted in an improvement of the total volatile fatty acids (VFA) production and modified the ratio between the VFA: there was a slight decrease in

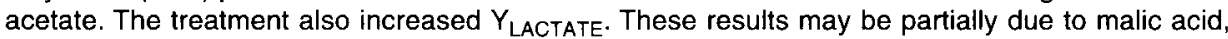
present in the YEA-SACC. Malic acid was shown to stimulate the growth rate (after $8 \mathrm{~h}$ of incubation) of $M$ elsdenii when amounts of 1,5 or $10 \mathrm{mM}$ were added to the culture medium.
\end{abstract}

lactate utilization / bacterial growth / Megasphaera elsdenii/ Saccharomyces cerevisiae

Résumé - Effet d'une culture de Saccharomyces cerevisiae sur la croissance et l'utilisation de l'acide lactique par la bactérie du rumen Megasphaera elsdenii. Ce travail étudie l'effet d'un filtrat de levure stérilisé sur la croissance et le métabolisme de l'acide lactique par la bactérie du rumen Megasphaera elsdenii. Le traitement a été effectué à 4 niveaux $0,1,2,5$ et $5 \%(\mathrm{~V} / \mathrm{V})$. Pour la préparation du filtrat, $5 \mathrm{~g}$ de levure (YEA-SACC) ont été agités pendant $1 \mathrm{~h}$ dans $50 \mathrm{ml}$ d'eau bidistillée. La suspension obtenue a été filtrée sur papier filtre et stérilisée par filtres ayant une porosité de $0,45 \mu \mathrm{m} . \mathrm{M}$ elsdenii a été cultivée à $39^{\circ} \mathrm{C}$ pendant $24 \mathrm{~h}$, en anaérobiose. Tous les traitements appliqués ont amélioré la capacité à métaboliser l'acide lactique, et la synthèse de matière sèche bactérienne. Les résultats ont été proportionnels à la quantité du filtrat ajouté. Les 2 paramètres pris en considération ont montré une amélioration de $60 \%$ pour le niveau le plus élevé $(5 \%)$. L'efficacité de croissance ( $\left.Y_{\text {LACTATE }}\right)$ a été uniquement améliorée par le traitement intermédiaire. La production d'acides gras volatils (AGV) est augmentée à 2,5 et $5 \%$. Les ratios molaires entre AGV ont été également changés montrant une diminution de l'acide acétique. Ces effets peuvent être partiellement dus à la présence d'acide malique dans le filtrat utilisé. En effet, en ajoutant $10 \mathrm{mM}$ d'acide malique, la vitesse de croissance de $\mathrm{M}$ elsdenii augmente.

utilisation du lactate / croissance bactérienne /Megasphaera elsdenii / Saccharomyces cerevisiae 


\section{INTRODUCTION}

The high amount of starch in ruminant diets stimulates the growth of amylolytic and lactate-producing rumen bacteria, such as Streptococcus bovis. The large amount of lactic acid produced by these organisms leads to a decrease in ruminal $\mathrm{pH}$ that results in the inhibition of cellulolytic and hemicellulolytic bacteria and, consequently, in rumen disorders (acidosis). Although some ruminal bacteria, such as Megasphaera elsdenii, Selenomonas ruminantium and Veillonella parvula, can utilize lactate as a carbon source, their metabolic activities are usually not sufficient to reduce the lactate levels to physiological concentrations. $M$ elsdenii is considered to be the main utilizer of lactate in the rumen (Counotte et al, 1981, 1983). Its metabolization is not inhibited by soluble sugars (Russell and Baldwin, 1978). The addition of yeast culture to the ruminant diet may be an effective tool to modify ruminal fermentative pattern (Williams et al, 1991; Carro et al, 1992); however, its effect on fiber digestion is still controversial (Chademana and Offer, 1990; Williams et al, 1991; Mir and Mir, 1994). The rumen lactate concentration in steers fed rolled barley plus hay (50:50) was lowered by the addition of yeast culture to the diet (Williams et al, 1991). Nisbet and Martin (1991) were able to improve the growth and lactate utilization in $S$ ruminantium with a supplement of yeast culture filter-sterilized filtrate. Factors affecting lactate uptake by $M$ elsdenii have been recently examined by Waldrip and Martin (1993). The aim of this work was to understand the effect of a Saccharomyces cerevisiae culture (YEA-SACC) on lactate utilization and growth of $M$ elsdenii.

\section{MATERIALS AND METHODS}

\section{Organism and culture conditions}

The strain type ATCC 25940 of $M$ elsdenii was used in this work. The strain was cultured normaily in ATCC 566 modified medium, that was composed as follows: (per liter) $\mathrm{KH}_{2} \mathrm{PO}_{4}, 1.6 \mathrm{~g}$; $\mathrm{K}_{2} \mathrm{HPO}_{4}, 3.2 \mathrm{~g}$; yeast extract, $4.0 \mathrm{~g} ; \mathrm{NH}_{4} \mathrm{Cl}, 0.5 \mathrm{~g}$; $\mathrm{CaCl}_{2}, 0.2 \mathrm{~g} ; \mathrm{MgCl}_{2}, 0.2 \mathrm{~g} ;$ Cysteine-HCl, $0.5 \mathrm{~g}$; sodium D-L lactate solution $60 \% \mathrm{w} / \mathrm{v}, 16 \mathrm{ml}$.

The $M$ elsdenii was cultured in batch culture at $39^{\circ} \mathrm{C}$ in an anaerobic glove box (Forma Scientific, Marietta, Ohio, USA), with an atmosphere composed of $10 \% \mathrm{CO}_{2}, 5 \% \mathrm{H}_{2}$ and $85 \% \mathrm{~N}_{2}$. Glassware and plasticware were exposed to the anaerobic atmosphere within the glove box for at least $48 \mathrm{~h}$ before being utilized.

Table I. Effect of Saccharomyces cerevisiae culture (YEA-SACC) filter-sterilized filtrate on lactate uptake by whole cells of Megasphaera elsdenii.

$\begin{array}{lcr}\text { YEA-SACC \% }(v / v) & \text { Lactate utilized }(\mathrm{mg} / 100 \mathrm{ml}) & \text { Variations compared } \\ & & \\ 0 & 817.36^{\mathrm{Aa}} & +26.5 \% \\ 1 & 1033.45^{\mathrm{ABb}} & +32.8 \% \\ 2.5 & 1085.07^{\mathrm{B}} & +63.4 \% \\ 5 & 1335.00^{\mathrm{C}} & \end{array}$

$\mathrm{SE}=64.70 ;$ least squares means with different letters are significantly different: $\mathrm{a}, \mathrm{b}(P<0.05) ; \mathrm{A}, \mathrm{B}(P<0.01)$ 


\section{Growth studies}

The effect of the YEA-SACC filtrate on the growth of $M$ elsdenii ATCC 25940 was determined. Because YEA-SACC contains an insoluble component, a sterile filtrate was prepared as previously described (Nisbet and Martin, 1991). The YEA-SACC filtrate was added under anaerobic condition to the medium in the following concentrations: 0 (control), $1,2.5$ and $5 \%$ of the medium ( $n=7$ for each level).

The effects of YEA-SACC filtrate on lactate utilization and $Y_{\text {LACTATE }}$ (mg bacterial dry matter produced $/ \mathrm{mM}$ of lactate metabolized) were studied. To study the effect of L-malate on bacterial growth, 1, 5, $10 \mathrm{mM} \mathrm{L}$-malate, from a $500 \mathrm{mM}$ stock solution, previously filtered and sterilized under anaerobic conditions, were added to the medium ( $n=4$ for each level). Growth studies were performed in $50 \mathrm{ml}$ flasks of ATCC $566 \mathrm{mod}-$ ified medium, inoculated with $0.5 \mathrm{ml}$ of overnight cultures of $M$ elsdenii ATCC 25940 and incubated at $39^{\circ} \mathrm{C}$ in anaerobic glove boxes for $24 \mathrm{~h}$ (YEASACC).

At the end of the fermentation, cells were recovered by centrifugation at $10000 \times \mathrm{g}$ for 15 $\min$ at $4{ }^{\circ} \mathrm{C}$, washed with bidistilled sterile water and resuspended in $1 \mathrm{ml}$ of sterile water. The dry weight of the washed cell suspension was determined after drying at $105^{\circ} \mathrm{C}$ for $3 \mathrm{~h}$ as previously described (Russell, 1986). Cell free supernatant was collected and stored $a-20^{\circ} \mathrm{C}$. Volatile fatty acids (VFA) and lactate were analyzed by gas chromatography (Varian model 3700 ) according to the method of Fussell and McCailey (1987). The optical density of the cultures, at $600 \mathrm{~nm}$ (Shimidzu spectrophotometer), was measured spectrophotometrically against a blank of noninoculated medium.

The data were analyzed by a one-way analysis of variance, the GLM procedure of the SAS statistical package (SAS, 1988). For growth data analysis, values were assumed to be statistically different $(P<0.05$; Russell and Chen, 1989) when the coefficient of variability ( $\mathrm{CV}$ ) was less than $10 \%$ and the differences among means were greater than 3 times the SD. If $\mathrm{CV}$ was greater than $10 \%$, significance $(P<0.10)$ was determined using a Student's $t$-test (Steel and Torrie, 1980).

\section{RESULTS}

Supplementing the growth medium with YEA-SACC improved the lactate utilization of growing cells of $M$ elsdenii. As shown in table I, increasing the concentration of the YEA-SACC filtrate in the medium led to increased lactate utilization. When $5 \%$ filtrate was added, the lactate utilization was much higher than the control $(+63.4 \%)$; however, it also increased with $1 \%$ supplement of YEA-SACC to the medium (26.5\%). Higher rates of lactate fermentation are confirmed by the acetate, propionate, butyrate and valerate production, which are consistent with the known end products of lactate metabolism by $M$ elsdenii (Rogosa, 1984). Supplementing the growth medium with 2.5 and $5 \%$ of YEA-SACC filtrate increased total VFA production (table II), with a higher production of VFA being found at the higher concentration of YEA-SACC. The molar \% of fatty acids were also slightly different. There was a tendency for the acetate production to decrease when $2.5 \%$ of YEASACC was added to the medium (table II).

The YEA-SACC supplementation stimulated the growth of $M$ elsdenii on lactate, calculated as the increase of microbial dry matter production (table III). This increment was linearly related to YEA-SACC filtrate concentration (table III). The same results were obtained when $M$ elsdenii's growth was monitored as the optical density of the bacterial culture (table IV). The optical density was $25 \%(6 h)$ and $50 \%$ higher $(9 h)$ for the $5 \%$ supplement as compared to the control.

The $Y_{\text {LACTATE }}$ values after treatment with $1,2.5$ and $5 \%$ of YEA-SACC filtrate are reported in table $V$. The $Y_{\text {LACTATE }}$ of $\mathrm{M}$ elsdenii was $10.46 \mathrm{~g}$ of cells per mole of lactate when $1 \%$ YEA-SACC was supplemented. It was 11.78 when the $2.5 \%$ of YEA-SACC filtrate was added. When $5 \%$ of YEA-SACC 
Table II. Effect of Saccharomyces cerevisiae culture (YEA-SACC) filter-sterilized filtrate on volatile fatty acid (VFA) production by Megasphara elsdenii culture.

YEA-SACC

$\%(V / V)$

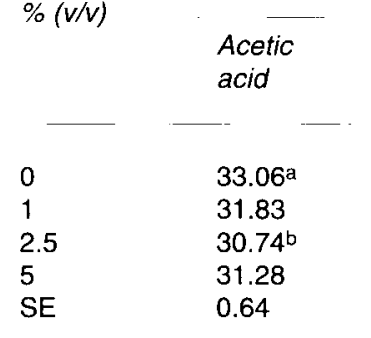

Molar percentage of VFA

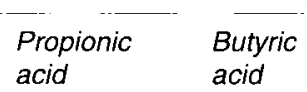

46.09

48.03

48.79

49.41

1.513

10.89

9.59

10.60

10.08

0.843

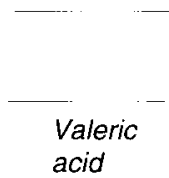
acid

9.96
10.55
9.87
9.22
1.263

VFA production ( $\mathrm{mg} / 100 \mathrm{ml}$ ) $774.10^{a}$

$782.41^{\mathrm{a}}$

$858.60^{\mathrm{b}}$

51.62 $869.52^{b}$

Least squares means, in the same column, with different letters are significantly different: $\mathrm{a}, \mathrm{b}(P<0.10)$.

filtrate was added, the $Y_{\text {LACTATE }}$ decreased to a value similar to the control. $M$ elsdenii growth, after $8 \mathrm{~h}$ of fermentation, was linearly increased when adding different concentrations of malic acid (table VI). The increment responses of $\mathrm{OD}_{600}$ were 5.62 , 11.36 and $12.21 \%$, respectively, for 1,5 and $10 \mathrm{mM}$ of malate concentration.

Table III. Effect of Saccharomyces cerevisiae culture (YEA-SACC) filter-sterilized filtrate on bacterial dry matter (DM) production by Megasphaera elsdenii culture.

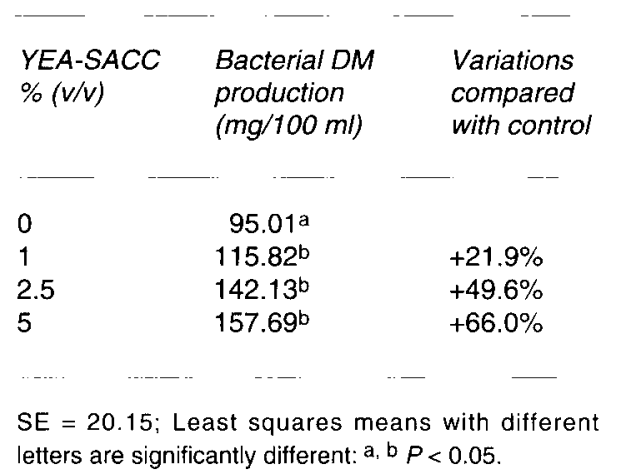

\section{DISCUSSION}

When adding $2.5 \%$ of YEA-SACC filtrate, the improvement in the amount of bacterial dry matter production was higher than the increase in lactate utilization, suggesting a better efficiency of lactate utilization for microbial synthesis. This hypothesis is sup-

Table IV. Effect of Saccharomyces cerevisiae culture (YEA-SACC) filter-sterilized filtrate on the growth of Megasphaera elsdenii on lactate.

\section{Time of incubation (h)}

\begin{tabular}{cc}
\multicolumn{2}{c}{ Absorbance at $600 \mathrm{~nm}$} \\
& \\
Control & \\
& \\
0.046 & 0.053 \\
0.108 & 0.113 \\
0.422 & 0.449 \\
0.788 & 0.996 \\
$1.021^{\mathrm{a}}$ & $1.426^{\mathrm{b}}$ \\
$1.012^{\mathrm{a}}$ & $1.517^{\mathrm{b}}$ \\
$1.285^{\mathrm{a}}$ & $1.476^{\mathrm{b}}$
\end{tabular}

* $5 \% \mathrm{v} / \mathrm{v}$; least squares means with different letters are significantly different: $\mathrm{a}, \mathrm{b} P<0.05$. 
Table V. Effect of Saccharomyces cerevisiae culture (YEA-SACC) filter-sterilized filtrate on growth yields of lactate grown cells of Megasphaera elsdenii.

$\begin{array}{ll}\begin{array}{l}\text { YEA-SACC } \\ \%(V / V)\end{array} & \begin{array}{l}Y_{\text {LACTATE }} \\ (\mathrm{mg} \text { cell/S/mM lactate } \\ \text { metabolized })\end{array} \\ & \\ 0 & 10.46 \\ 1 & 10.09 \\ 2.5 & 11.78 \\ 5 & 10.63\end{array}$

$\mathrm{SE}=1.20$.

ported by a parallel behavior of $Y_{\text {LACTATE }}$, which reached a maximum at $2.5 \%$ supplementation. A similar result was obtained by Nisbet and Martin (1991), who studied the effect of YEA-SACC on lactate uptake by $S$ ruminantium.

The effects of YEA-SACC filtrate on VFA pattern and production are partially in agreement with other studies, which show an increase in VFA production and a decrease in acetate and propionate molar percentage, following addition of YEA-SACC to pure cultures of different rumen microorganisms (Harrison et al, 1988; Nisbet and Martin, 1991).

Using Aspergillus oryzae (Amaferm) fermentation extract filtrate, Waldrip and Martin (1993) obtained a reduction in acetate production and an increase in the molar percentage of valeric acid by $M$ elsdenii.

Based on the effects on lactate utilization, VFA production and growth stimulation, the addition of YEA-SACC filtrate must provide one or more soluble factors which stimulate lactate metabolism of $M$ elsdenii. The role of amino acids is not clear. Waldrip and Martin (1993) showed that Amaferm stimulated growth of $\mathrm{Mels}$ denii in the absence of Trypticase only. According to this data, stimulation seems to be due to the amino acid content of the filtrate.

According to Wallace (1986), amino acids are probably not involved, in growth stimulation, because they meet only $37 \%$ of the energy maintenance requirements of $M$ elsdenii.

Table VI. Effect of different concentrations of malic acid on the growth of Megasphaera elsdenii on lactate.

Time of

incubations

(h)

Control
Absorbance at $600 \mathrm{~nm}$

$\begin{array}{lll} & \text { Malate } & \\ 1 \mathrm{mM} & 5 \mathrm{mM} & 10 \mathrm{mM} \\ & & \\ 0.069 & 0.098^{\mathrm{b}} & 0.033 \\ 0.343 & 0.359 & 0.176 \\ 0.861 & 0.936^{\mathrm{b}} & 0.875 \\ 1.082^{*} & 1.150^{*} & 1.085 \\ 1.202^{\mathrm{b}} & 1.267^{\mathrm{b}} & 1.277^{\mathrm{b}} \\ 1.250 & 1.286 & 1.341\end{array}$

a, b Means significantly different from the control $(P<0.05)$; ${ }^{*}$ means significantly different from the control $(P<0.10)$. 
Lactate uptake by $M$ elsdenii was unchanged when sugars (Hino et al, 1994) or $\mathrm{Na}^{+}$and $\mathrm{K}^{+}$(Waldrip and Martin, 1993) were added to the medium. Uncoupling agents causing diffusion of protons into the cell strongly reduced lactate utilization by $M$ elsdenii, whereas ionophores and ATPase inhibitors had a poor inhibitory effect on lactate utilization (Waldrip and Martin, 1993). Based on their results, Waldrip and Martin (1993) suggested that a proton motive force-driven mechanism may be involved in L-lactate uptake by $M$ elsdenii.

Since Nisbet and Martin (1991) showed that organic acids from the YEA-SACC filtrate, particularly malate, stimulate $S$ ruminantium growth, we investigated the influence of malic acid on $M$ elsdenii growth. Our experiment demonstrated that growh rate of $M$ elsdenii was increased slightly by adding malic acid (table VI).

The YEA-SACC filtrate was assayed for L-malate content and found to contain a 4.2 $\mathrm{mM}$ of L-malate. Thus, when adding $2.5 \%$ of YEA-SACC, the final concentration of malate was only $0.21 \mathrm{mM}$, which would therefore play a minor role in stimulating the growth of $M$ elsdenii.

\section{CONCLUSION}

YEA-SACC filter-sterilized filtrate increased the growth, lactate uptake, pattern and VFA production in $M$ elsdenii cultures. An improvement in microbial synthesis efficiency, as a function of supplementation level, was also observed. The malic acid content of YEA-SACC filtrate explains only a small part of the probiotic activity observed. Further studies will be necessary to detect which substances in YEA-SACC are the most important in stimulating the metabolic activity of $M$ elsdenii.

\section{ACKNOWLEDGMENTS}

Thanks are due to M Callegari and M Moschini for their help in the preparation of this paper. This research was supported by the National Research Council of Italy, Special Project RAISA, Subproject no 3, paper no 1660.

\section{REFERENCES}

Carro MD, Lebzien P, Rohr K (1992) Influence of yeast culture on the in vitro fermentation (Rusitec) of diets containing variable portions of concentrates. Anim Feed Sci Technol 37, 209-220

Chademana I, Offer NW (1990) The effect of dietary inclusion of yeast culture on digestion in sheep. Anim Prod 50, 483-489

Counotte GHM, Prins RA, Janssen RHAM, deBie MJA (1981) Role of Megasphaera elsdenii in the fermentation of $\mathrm{DL}-\left[2-{ }^{13} \mathrm{C}\right]$ lactate in the rumen dairy cattle. Appl Environ Microbiol 42, 649-655

Counotte GHM, Lankhorst A, Prins RA (1983) Role of DL-lactic acid as an intermediate in rumen metabolism of dairy cows. J Anim Sci 56, 1222-1235

Fussell RJ, McCailey DV (1987) Determination of volatile fatty acids $\left(\mathrm{C}_{2}-\mathrm{C}_{5}\right)$ and lactic acid in silage by gas chromatography. Analyst 112, 1213-1216

Harrison GA, Hemken RW, Barker KB, Dawson KA, Harmon RJ (1988) Influence of addition of yeast culture supplement to diets of lactating cows on ruminal fermentation and microbial populations. $J$ Dairy $S c i$ $71,2967-2975$

Hino T, Shimada K, Maryuama T (1994) Substrate preference in a strain of Megasphaera elsdenii a ruminal bacterium and its implication in propionate production and growth competition. Appl Environ Microbio/60, 1827-1831

Mir Z, Mir PS (1994) Effect of the addition of live yeast (Saccharomyces cerevisiae) on growth and carcass quality of steers fed high-forage of high-grain diets and on feed digestibility and in situ degradability. $J$ Anim Sci 72, 537-545

Nisbet DJ, Martin SA (1991) Effect of a Saccharomyces cerevisiae culture on lactate utilization by the ruminal bacterium Selenomonas ruminantium. J Anim SCi $69,4628-4633$

Rogosa M (1984) Anaerobic Gram negative cocci. In: Bergey's Manual of Systematic Bacteriology (JG Holt, ed), Williams \& Wilkins, Baltimore, London, 685 
Russell JB (1986) Heat production by ruminal bacteria and its relationship to maintenance energy. $J B a c$ teriol 169, 694-701

Russell JB, Baldwin RL (1978) Substrate preferences in rumen bacteria: evidence of catabolite regulatory mechanism. App/ Environ Microbiol 36, 319-329

Russell JB, Chen G (1989) Effects of monensin and pH on the production and utilization of pyro-glutamate, a novel product of ruminal glutamine deamination. J Anim Sci 67, 2370-2376

SAS Institute (1988) SAS-STAT User's Guide, Version 6, vol 1. SAS institute Inc, Cary, NC, USA

Somerville HJ (1968) Enzymic studies on the biosynthesis of amino acids from lactate by Peptostreptococcus elsdenii. Biochem J 108, 107-119
Steel RGD, Torrie JH (1980) Principles and procedures of statistics, a biometrical approach, 2nd ed. McGrawHill, New York, USA, $633 p$

Waldrip HM, Martin SA (1993) Effects of an Aspergillus oryzae fermentation extract and other factors on lactate utilization by the ruminal bacterium Megasphaera elsdenii. J Anim Sci 71, 2770-2776

Wallace RJ (1986) Catabolism of amino acids by Megasphaera elsdenii. Appl Environ Microbiol 51, 1141-1143

Williams PEV, Tait CAG, Innes GM, Newbold CJ (1991) Effects of the inclusion of yeast culture (Saccharomyces cerevisiae plus growth medium) in the diet of dairy cows on milk yield and forage degradation and fermentation patterns in the rumen of steers. J Anim Sci 69, 3016-3026 